\title{
Three-Year Investigation of Tillage Management on the Soil Physical Environment, Earthworm Populations and Crop Yields in Croatia
}

\author{
Igor Dekemati ${ }^{1}$, Barbara Simon ${ }^{2, *}$, Igor Bogunovic ${ }^{3}{ }^{\mathbb{D}}$, Szergej Vinogradov ${ }^{4}$, Maimela Maxwell Modiba ${ }^{1}$, \\ Csaba Gyuricza ${ }^{1}$ and Márta Birkás ${ }^{1}$
}

1 Department of Agronomy, Institute of Crop Production Sciences, Hungarian University of Agriculture and Life Sciences, H-2100 Gödöllő, Hungary; dekemati.igor@uni-mate.hu (I.D.); maxwell.maimela.modiba@hallgato.uni-szie.hu (M.M.M.); Gyuricza.Csaba@uni-mate.hu (C.G.); birkas.marta@uni-mate.hu (M.B.)

2 Department of Soil Science, Institute of Environmental Sciences, Hungarian University of Agriculture and Life Sciences, H-2100 Gödöllő, Hungary

3 Department of General Agronomy, Faculty of Agriculture, University of Zagreb, 10000 Zagreb, Croatia; ibogunovic@agr.hr

4 Department of Economics and Methodology, Institute of Economics, Hungarian University of Agriculture and Life Sciences, H-2100 Gödöllő, Hungary; vinogradov.szergej@uni-mate.hu

* Correspondence: simon.barbara@uni-mate.hu; Tel.: +36-28-522 (ext. 1818)

Citation: Dekemati, I.; Simon, B.; Bogunovic, I.; Vinogradov, S.; Modiba, M.M.; Gyuricza, C.; Birkás, M. Three-Year Investigation of Tillage Management on the Soil Physical Environment, Earthworm Populations and Crop Yields in Croatia. Agronomy 2021, 11, 825. https://doi.org/10.3390/agronomy 11050825

Academic Editors: Ajit Govind and Bhupinder Pal Singh

Received: 12 March 2021

Accepted: 20 April 2021

Published: 22 April 2021

Publisher's Note: MDPI stays neutral with regard to jurisdictional claims in published maps and institutional affiliations.

Copyright: (c) 2021 by the authors. Licensee MDPI, Basel, Switzerland. This article is an open access article distributed under the terms and conditions of the Creative Commons Attribution (CC BY) license (https:/ / creativecommons.org/licenses/by/ $4.0 /)$.
Abstract: The aim of this study was to determine the environmental suitability of conservation tillage systems. A 3-year experiment was conducted in Croatia, to study the effects of different tillage treatments on soil properties, with the following: deep (DC), shallow tine cultivation (SC) and ploughing (P). Soil penetration resistance (SPR) was significantly greater in P compared to DC in all three years. In 2016, it was found at 30-40 and 40-50 cm; in 2017 at 10-20 cm; in 2018 at 0-10 and $10-20 \mathrm{~cm}$. However, SC was significantly greater at 20-30, 30-40 and 40-50 cm compared to P and DC in 2017. The greater surface coverage in DC and SC ( $>30 \%)$ as compared to $\mathrm{P}(<1 \%)$ provided significantly higher soil moisture content (SMC) in maize (2016) and soybean (2018). In 2017, SMC in SC was significantly lower than in P and DC. Regarding all the 3 years, the agronomic structure in DC and SC had significantly greater crumb ratio compared to $\mathrm{P}$, whereas $\mathrm{P}$ had significantly higher dust ratio than DC and SC. Throughout the 15 measurements, DC provided the most favorable soil habitat (11 occasions out of 15). In 2017, the earthworm abundance was significantly higher in DC compared to SC. In all the three years, DC resulted the highest yield, however the difference was not significant. Higher surface coverage and SMC positively impacted the ratio of agronomic structure (decreased dust and increased crumb ratio) and earthworm abundance. It can be concluded that DC and SC provided greater soil coverage which positively affected SPR, SMC, agronomic structure and earthworm abundance as compared to P.

Keywords: tillage; soil penetration resistance; soil moisture content; agronomic structure; earthworms; crop yield

\section{Introduction}

World population is gradually growing and reached 7.674 billion people in 2019 [1] Such growth increases the demand for food, fiber and fuel. In this context, soil has been and will be one of the most valuable resources of mankind [2] since it is the support for $95 \%$ of food production [3]. To satisfy future population growth, it is necessary to preserve all productive soil, however, 33 million hectares of arable land is already severely degraded only in Europe [4]. Despite soil degradation, the negative effects of climate change on plant-soil relationship reduce food production $[5,6]$.

Precipitation and air temperature, as the most important climatic factors, are under significant changes. According to climate change projections, precipitation decreases, and 
its distribution will be extreme during summer times [7]. As a result, crop yields also declined or fluctuated, depending on climatic conditions (extreme, long drought or heavy rainfall), which could result complete or partial yield loss [8].

From the beginning of the 21st century, conservation agriculture (CA) has received more attention, due to positive outcomes of adoption. Primarily, CA reduces the number of passes $[6,9,10]$ and provides higher residue cover [11]. The positive effects of reduced soil disturbance and higher surface cover with the aim of conserving soil moisture content (SMC) had been reported in several studies [12-15]. Kalmár et al. (2013) [13] highlighted that the surface cover greatly impacts SMC. Moreover, with higher residue content SMC increases, which positively effects SPR. Dekemati et al. (2019b) [16] observed important changes in soil penetration resistance (SPR), i.e., as the drier season arrives, ploughed soil as compared to CA, rapidly loses SMC which increases SPR.

The soil cover protects soil agronomic structure [17]. According to results from eight experimental years, Dekemati et al. (2019a) [18] pointed out that deep tine cultivation (DC) provided significantly higher crumb ratio $(80.5 \%)$ as compared to ploughing $(\mathrm{P})(70.0 \%)$, however there was no difference between DC and shallow tine cultivation (SC). In addition, Bogunovic et al. (2019) [19] found in a three-year investigation that DC significantly influenced crumb ratio, it provided $7.3-16.1 \%$ more crumbs as compared to P. Moreover, in the last year of the experiment $P$ had only $50.0 \%$ crumbs, while the other $50.0 \%$ was clod and dust.

A high proportion of dust is the result of unfavourable tillage and an indicator of poor soil quality. In case of traditional ploughing, these particles are exposed to wind erosion, or they can be leached further in deeper layers and accumulate in the deepest tilled layer [20]. Birkás et al. (2017b) [21] reported that soil settling became a typical phenomenon in the Central European region, however, it was strongly dependent on soil quality. Furthermore, ploughing in many cases led to severe soil degradation that has affected the environment and microbial biodiversity [22-24].

Earthworms, as the most significant member of macrofauna [25], are considered important ecosystem engineers and most valuable indicators of soil biology [26-28]. They play a significant role in soil formation and soil profile development since they can consume 20-30 times their body weight daily [29]. However, intensification of agriculture may reduce soil biodiversity [30]. Earthworms are particularly sensitive to tillage as a mechanical modification of soil physical conditions. Studies have shown how direct mechanical interventions cause $50 \%$ damage or even kill earthworms [31,32]. In addition, they can indirectly drastically change the soil environment by removing plant residues as insulating material and food source and modify SMC, temperature, structure and soil $\mathrm{pH}[33,34]$.

In spite of all the positive effects of CA mentioned above, there are still several limiting factors [35-37]. For instance, the applicability of CA is limited by the small farm sizes, shortage of modern machinery [38] and reaching of different yields [24,39,40]. Despite that, conventional tillage (ploughing) still dominates worldwide, especially in Europe [40] and Croatia [41,42].

The objective of our research was to examine the effects of three different tillage treatments on soil physical properties (soil moisture content, penetration resistance and soil structure), earthworm abundance and crop yields in Croatia.

The hypothesis is that CA treatments (deep and shallow tine cultivation) will result in more favorable soil conditions (greater soil moisture content, higher crumb ratio), which provide a better habitat for earthworms and higher crop yields as compared to ploughing.

\section{Materials and Methods}

\subsection{Study Site and Description of the Experiments}

The tillage experiment was set up on the border of Lukač $\left(45^{\circ} 55^{\prime} \mathrm{N} ; 17^{\circ} 29^{\prime} \mathrm{E}, 103 \mathrm{~m}\right.$ a.s.l.) in the Pannonian region (Virovitica-Drava county) between 2015 and 2018 (Figure 1). The area is mostly flat, with slope between $0^{\circ}$ and $2^{\circ}$ and land use cover was dominantly under croplands. The soil on experimental field belongs to Luvic Stagnosol (Siltic) with 
a silt loam texture [43] (IUSS Working Group WRB, 2015). According to depths, at depth $0-15 \mathrm{~cm}$, soil is silty loam ( $28.8 \%$ sand, $49.5 \%$ silt and $21.7 \%$ clay), $\mathrm{pH}\left(\mathrm{H}_{2} \mathrm{O}\right) 7.8$ and organic carbon content is $2.23 \%$, while at $15-30 \mathrm{~cm}$ depth, soil is silty loam $(27.7 \%$ sand, $50.8 \%$ silt and $21.5 \%$ clay), $\mathrm{pH}\left(\mathrm{H}_{2} \mathrm{O}\right) 8.0$ and organic carbon $1.48 \%$.

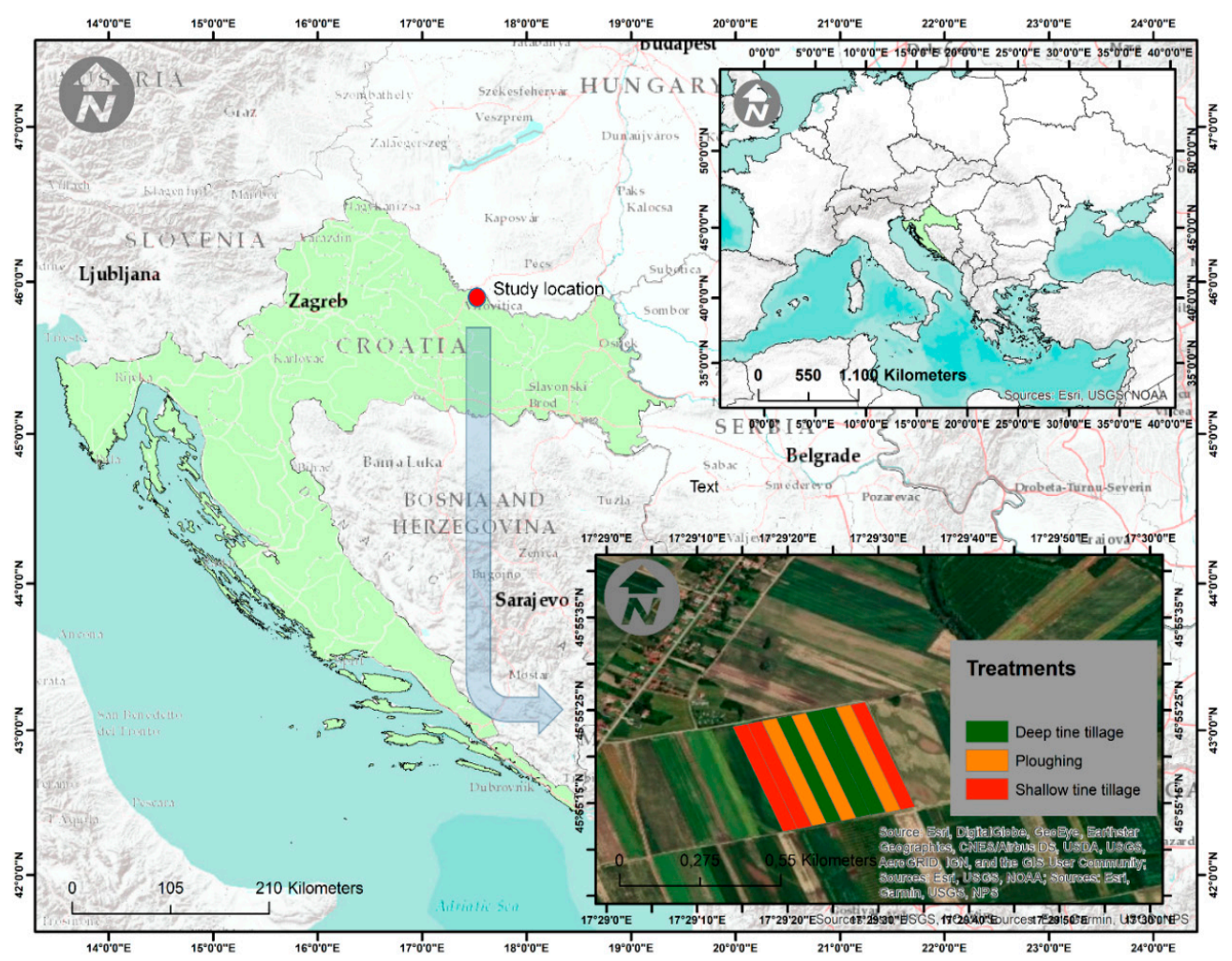

Figure 1. Location of the experiment in Croatian and Central European relation.

During the 2015/2016 season, ploughing (P) and deep tine cultivation (DC) was studied, while in the next two seasons shallow tine cultivation (SC) was added as a treatment for evaluation. Each tillage treatment had three replicates. The individual plot area was $7500 \mathrm{~m}^{2}$ ( $375 \mathrm{~m}$ long and $20 \mathrm{~m}$ wide). The tillage management data are shown in Table 1, while the data of crop production technology are shown in Table 2.

Table 1. List of tillage treatments, applied equipment, working depths, widths in the experiment.

\begin{tabular}{llcc}
\hline \multicolumn{1}{c}{ Treatments } & Tillage Equipment & Tillage Depth $\mathbf{( c m )}$ & Tillage Width (cm) \\
\hline Shallow tine cultivation & Väderstad Cultus 300 & $18-20$ & 300 \\
\hline Deep tine cultivation & Väderstad Cultus 300 & $22-25$ & 300 \\
\hline Ploughing & Vogel\&Noot 1050 & $30-32$ & 160 \\
\hline
\end{tabular}

\subsection{Meteorological Data}

The climate is continental with usually warmer autumn than spring. The average annual air temperature was $10.7^{\circ} \mathrm{C}$, and the average annual rainfall for the period 1965-1995 was $815.5 \mathrm{~mm}$. During this time, the lowest measured average precipitation was $552.6 \mathrm{~mm}$ (1971), while the highest was $1114.8 \mathrm{~mm}$ (1972). Precipitation and temperature data (Virovitica Station) were obtained from the National Meteorological Service of Croatia (Figure 2). 
Table 2. The timetable of agricultural management.

\begin{tabular}{|c|c|c|c|}
\hline & \multicolumn{3}{|c|}{ Year, Crop } \\
\hline Vegetation & 2015/2016 Maize & $2016 / 2017$ winter oat & 2017/2018 soybean \\
\hline Tillage & 5 October 2015 & 10 October 2016 & 27 September 2017 \\
\hline Seedbed preparation & 10 April 2016 & 22 October 2016 & 20 April 2018 \\
\hline Seeding & 11 April 2016 & 25 October 2016 & 24 April 2018 \\
\hline Variety & LG 33.30 (FAO 340) & RWA Wiland & RWA Xonia (00) \\
\hline Seeding rate & 64,000 seeds ha ${ }^{-1}$ & $150 \mathrm{~kg} \mathrm{ha}^{-1}$ & 600,000 seeds ha ${ }^{-1}$ \\
\hline Fertilizers & $\begin{array}{c}300 \mathrm{~kg} \mathrm{ha}^{-1} \text { NPK }(7: 20: 30) \\
\text { (3 October } 2015) ; \\
400 \mathrm{~kg} \mathrm{ha}^{-1} \mathrm{NPK} \\
(15: 15: 15)(11 \text { April 2016) + } \\
\text { N:27 (19 May 2016) }\end{array}$ & $\begin{array}{l}200 \mathrm{~kg} \mathrm{ha}{ }^{-1} \text { NPK }(15: 15: 15) \\
\text { (21 October 2016); } \\
\text { 1st top dressing } 150 \mathrm{~kg} \mathrm{ha}^{-1} \mathrm{~N}: 27 \\
\text { (16 March 2017); } \\
2 \text { top dressing } 100 \mathrm{~kg} \mathrm{ha}^{-1} \mathrm{~N}: 27 \\
\quad(10 \text { May 2017) }\end{array}$ & $\begin{array}{l}300 \mathrm{~kg} \mathrm{ha}^{-1} \\
\text { NPK }(15: 15: 15) \\
24 \text { April 2018 }\end{array}$ \\
\hline Crop protection * & $\begin{array}{l}1 \mathrm{~L} \mathrm{ha}^{-1} \text { Elumis }+20 \mathrm{~g} \\
\mathrm{ha}^{-1} \text { Peak } 75 \mathrm{WG} \\
(2 \text { May 2016) }\end{array}$ & $\begin{array}{l}\text { Mustang 0.5 L ha } \\
\quad \text { (27 March 2017) } \\
\text { Karate Zeon 0.15 L ha-1 } \\
\quad \text { (10 May 2017) }\end{array}$ & $\begin{array}{c}\text { Laguna } 75 W G 100 \mathrm{~g} \mathrm{ha}^{-1}+\text { Harmony } \\
\text { 75WG } 8 \mathrm{~g} \mathrm{ha}^{-1}+\text { Trend } 90 \\
22 \text { May } 2018\end{array}$ \\
\hline Harvesting & 3 October 2016 & 5 July 2017 & 10 September 2018 \\
\hline Growing period (day) & 177 & 253 & 139 \\
\hline
\end{tabular}

* Active ingredients in Elumis Peak combination $(75 \mathrm{~g} / \mathrm{L}$ mesotrione $+30 \mathrm{~g} / \mathrm{L}$ nicosulfuron $+750 \mathrm{~g} / \mathrm{L}$ prosulfuron); Mustang $(6 \mathrm{~g} / \mathrm{L}$ florasulam $+450 \mathrm{~g} / \mathrm{L} 2,4 \mathrm{D}$ dichlorophenoxyacetic acid); Karate Zeon $(50 \mathrm{~g} / \mathrm{kg}$ lambda-cihalotrin); Laguna $75 \mathrm{WG}$ (750 g/kg oxasulfuron); Harmony 75 WG (500 g/ kg thifensulfuron-methyl); Trend 90 (90\% alkyl aryl polyethoxy ethers and other ethoxylated derivatives, fatty acid, isopropanol).

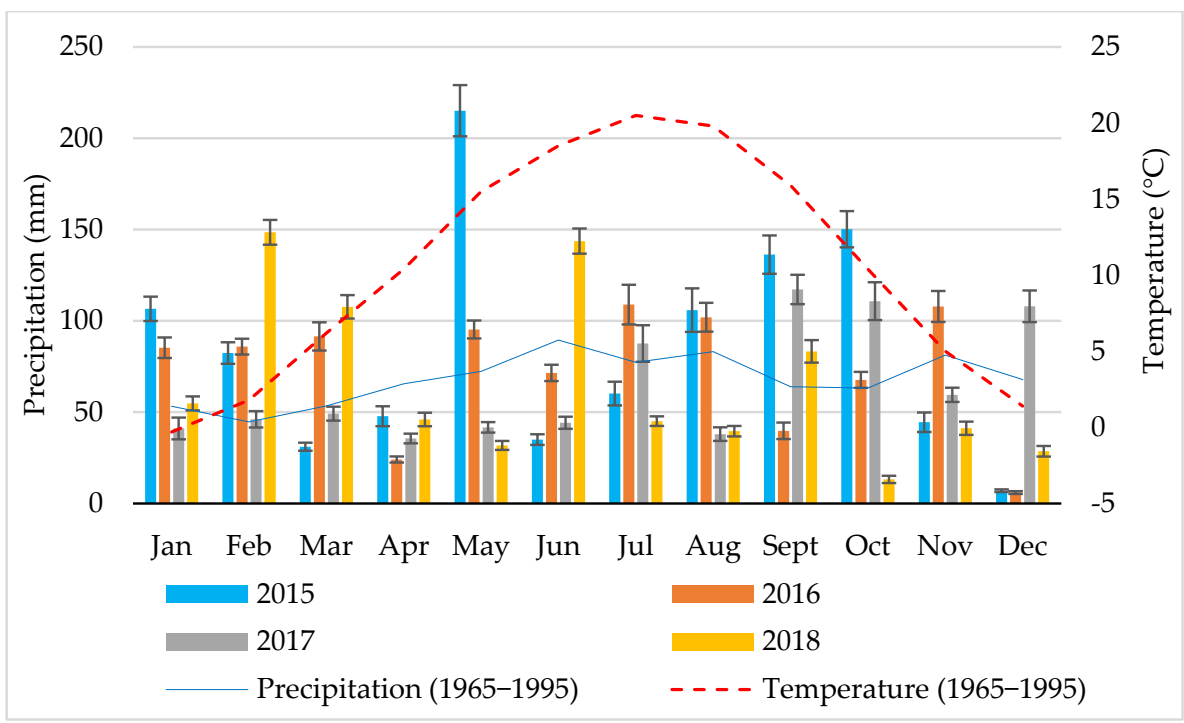

Figure 2. Monthly average precipitation and temperature between 2015 and 2018 and the long-term monthly average 1965-1995.

\subsection{Soil Sampling, Field Measurements and Laboratory Analyses}

The soil conditions were measured five times per year over three growing seasons, from early spring to late autumn (Table 3). Soil penetration resistance (SPR) was measured with an electronic hand-pushed cone penetrometer (Penetrologger, Eijkelkamp, Netherland) using a cone with $1 \mathrm{~cm}^{2}$ base area, with a $60^{\circ}$ included angle and $80 \mathrm{~cm}$ driving shaft. In total, 9 sampling points per treatment were measured at each sampling date and the data were grouped at $10 \mathrm{~cm}$ interval to a depth of $50 \mathrm{~cm}$. Simultaneously to SPR measurements, the soil moisture content (SMC) was measured with a PT-I type measuring instrument 
(Kapacitív Kft., Budapest) in vicinity of each SPR measurement from 0-50 cm depth in $10 \mathrm{~cm}$ increment. The SMC was expressed in $\%\left(\mathrm{~g} \mathrm{~g}^{-1}\right)$.

Table 3. Timetable for the measurements for soil condition.

\begin{tabular}{cccc}
\hline & \multicolumn{3}{c}{ Year of Vegetation } \\
\cline { 2 - 4 } & 2015/2016 & 2016/2017 & $2017 / 2018$ \\
\cline { 2 - 4 } & 12 April & 15 November & 16 October \\
Date of Measurements & 22 June & 20 March & 24 April \\
& 22 July & 20 April & 28 June \\
& 16 August & 22 May & 21 July \\
& 22 September & 21 June & 17 October \\
\hline
\end{tabular}

The study of the soil structure was performed according to the classification of Stefanovits (1992) [44]. Sampling was performed at the 0-10 cm depth in three replicates per treatment in each sampling period. The soil samples were air-dried and then carefully sieved manually (60 shakes/min) on an agronomic sieve. Investigations of the ratio of different soil fractions such as clods $(>10 \mathrm{~mm})$, crumb $(2.5-10 \mathrm{~mm})$, fine crumb $(0.25-2.5 \mathrm{~mm})$ and dust $(<0.25 \mathrm{~mm})$ give the real state about the effect of tillage treatments on soil structure and the consequences of weather effects. The soil structure ratio can be determined from the weight of the fractions [18].

The soil surface covering was determined digitally with Adobe Photoshop CC 2019. All treatments were tested in nine replicates. The recordings were made after tillage as well as after sowing. The photos have a resolution of $2272 \times 4608$ and cover a minimum area of $6 \mathrm{~m}^{2}$. The soil surface covering results are shown in percentages.

The earthworm population was examined by hand-sorting in situ from a volume of $18.75 \mathrm{dm}^{3}(25 \times 25 \mathrm{~cm}, 30 \mathrm{~cm}$ deep $)$ in all plots in nine replicates [45]. The duration of hand-sorting lasted about 30-40 min, depending on the physical status of the soil. The examined sites were chosen randomly and the distance between soil blocks was about 5-10 $\mathrm{m}$. The earthworms were sampled also like previous properties 15 times during three years (Table 3). The earthworm abundance was expressed in ind $\mathrm{m}^{-2}$ [16]. Crops were harvested each year from each plot with harvester and the grain yield was weighed, and grain moisture was determined. Grain yields were presented with $0 \%$ moisture.

\subsection{Statistical Analyses}

Before the statistical tests were carried out, the datasets were checked for normality using Kolmogorov-Smirnov test. Soil coverage, earthworm abundance and crop yields follow the Gaussian distribution, while the SMC and SPR follow the normal distribution only after logarithmic transformation. Soil aggregates did not follow the normal distribution even after logarithm and Box-Cox transformation. A factorial ANOVA design was carried out to identify differences in the SPR and SMC (factors: tillage, sampling time and soil depth). One-way analysis of variance was used to examine the significant differences between the tillage methods and the soil cover, categories in the agronomic structure, crop yields and the number of earthworms. In case of a significant result of the analysis of variance, the groups with a significant difference were determined by Tukey HSD post hoc test at a $p<0.05$. For soil aggregates, statistical comparisons were carried out with the non-parametric Kruskal-Wallis test $(\mathrm{K}-\mathrm{W})$. If significant differences at a $p<0.05$ were observed, a multiple comparison of mean ranks post-hoc test was applied. Statistical data processing was performed using the IBM SPSS Statistics 25 software package (IBM, Armonk, NY, USA).

\section{Results}

\subsection{Influence of Tillage on Surface Cover}

The soil cover data of the three-year experiment are presented in Figure 3. Soil cover is significantly lower in ploughing $(\mathrm{P})$ compared to shallow tine (SC) and deep tine cultivation 
(DC) in each studied year. Surface cover in P is less than $1 \%$ of the soil each year. In DC surface cover was between $28.6 \%$ and $42.0 \%$, while in SC it was between 36.1 and $46.0 \%$.

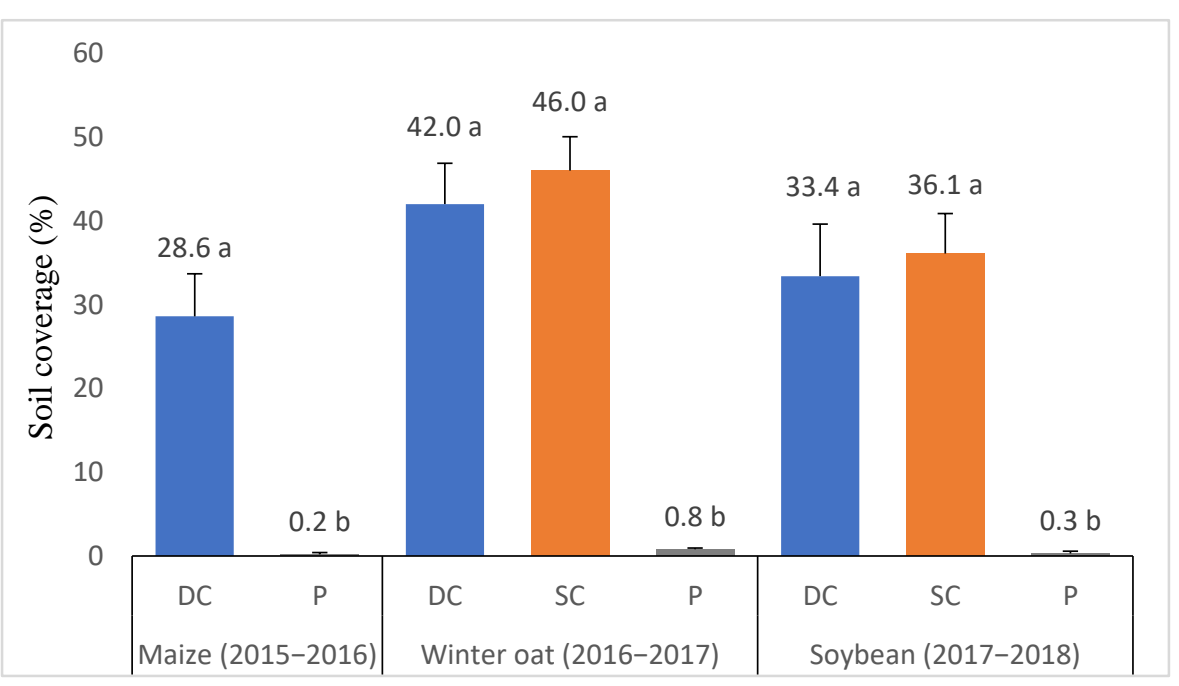

Figure 3. A soil cover $(\%)$ under tillage treatments. Hanging bars represent standard deviation. Different lowercase letters indicate significant difference $(p<0.05)$ between treatments in each studied season. Abbreviations: $\mathrm{P}$, ploughing; DC, deep tine tillage; SC, shallow tine tillage.

\subsection{Soil Penetration Resistance}

The soil penetration resistance (SPR) was significantly affected by tillage, year and depth and their interactions through all the three years of research (Table 4). Regarding the depths, SPR values were significantly higher with depths in all studied years. Depth $\times$ tillage interaction significantly increased SPR with depths at all treatments.

Table 4. (a) Results of factorial ANOVA analysis for SPR. (b) Mean SPR according to the time, tillage and soil depth.

\begin{tabular}{|c|c|c|c|c|c|c|c|c|c|c|c|}
\hline \multicolumn{12}{|l|}{ (a) } \\
\hline Year & 2016 & & & 2017 & & & & 2018 & & & \\
\hline Time $(\mathrm{T})$ & $* * *$ & & & $* * *$ & & & & $* * *$ & & & \\
\hline Tillage (Till) & $* * *$ & & & $* * *$ & & & & $* * *$ & & & \\
\hline Depth (D) & $* * *$ & & & $* * *$ & & & & $* * *$ & & & \\
\hline $\mathrm{T}^{*}$ Till & $* * *$ & & & $* * *$ & & & & $* * *$ & & & \\
\hline $\mathrm{T} * \mathrm{D}$ & $* *$ & & & $* * *$ & & & & $* * *$ & & & \\
\hline Till *D & * & & & $* * *$ & & & & $* * *$ & & & \\
\hline $\mathrm{T} *$ Till $* \mathrm{D}$ & * & & & * & & & & $* * *$ & & & \\
\hline \multicolumn{12}{|l|}{ (b) } \\
\hline Depth & $P$ & DC & Ave. & $\mathrm{P}$ & DC & SC & Ave. & $P$ & DC & SC & Ave. \\
\hline $0-10 \mathrm{~cm}$ & $2.33 \mathrm{Ea}$ & $1.95 \mathrm{Da}$ & $2.14 \mathrm{E}$ & $1.09 \mathrm{Da}$ & $1.05 \mathrm{Ea}$ & $1.12 \mathrm{Ea}$ & $1.09 \mathrm{E}$ & $1.46 \mathrm{Ea}$ & $0.93 \mathrm{~Eb}$ & $1.39 \mathrm{Ea}$ & $1.26 \mathrm{E}$ \\
\hline $10-20 \mathrm{~cm}$ & $2.91 \mathrm{Da}$ & $2.66 \mathrm{Ca}$ & $2.79 \mathrm{D}$ & $2.07 \mathrm{Ca}$ & $1.67 \mathrm{Db}$ & $1.94 \mathrm{Dab}$ & $1.89 \mathrm{D}$ & $2.01 \mathrm{Da}$ & $1.49 \mathrm{Db}$ & $1.80 \mathrm{Dab}$ & $1.77 \mathrm{D}$ \\
\hline $20-30 \mathrm{~cm}$ & $3.46 \mathrm{Ca}$ & $3.22 \mathrm{Ba}$ & $3.34 \mathrm{C}$ & $2.31 \mathrm{Cb}$ & $2.29 \mathrm{Cb}$ & $2.91 \mathrm{Ca}$ & $2.50 \mathrm{C}$ & $3.25 \mathrm{Ca}$ & $2.48 \mathrm{Cb}$ & $2.30 \mathrm{Cb}$ & $2.68 \mathrm{C}$ \\
\hline $30-40 \mathrm{~cm}$ & $4.01 \mathrm{Ba}$ & $3.50 \mathrm{Bb}$ & $3.76 \mathrm{~B}$ & $2.89 \mathrm{Bb}$ & $2.94 \mathrm{Bb}$ & 3.72 Ba & $3.19 \mathrm{~B}$ & $3.87 \mathrm{Ba}$ & $3.62 \mathrm{Ba}$ & $2.72 \mathrm{Bb}$ & $3.40 \mathrm{~B}$ \\
\hline $40-50 \mathrm{~cm}$ & $4.61 \mathrm{Aa}$ & $3.92 \mathrm{Ab}$ & $4.27 \mathrm{~A}$ & $3.44 \mathrm{Ab}$ & $3.42 \mathrm{Ab}$ & $4.28 \mathrm{Aa}$ & $3.72 \mathrm{~A}$ & $4.28 \mathrm{Aa}$ & $4.09 \mathrm{Aa}$ & $3.25 \mathrm{Ab}$ & $3.87 \mathrm{~A}$ \\
\hline \multicolumn{12}{|l|}{ Time } \\
\hline 1st measure & $2.21 \mathrm{Da}$ & $2.02 \mathrm{Ca}$ & $2.11 \mathrm{C}$ & $1.53 \mathrm{Db}$ & $1.36 \mathrm{Cb}$ & $1.94 \mathrm{Ca}$ & $1.61 \mathrm{D}$ & $2.24 \mathrm{a}$ & $2.16 \mathrm{a}$ & $2.15 \mathrm{a}$ & $2.18 \mathrm{C}$ \\
\hline 2nd measure & $3.46 \mathrm{Ba}$ & $3.23 \mathrm{Ba}$ & $3.35 \mathrm{~B}$ & $2.18 \mathrm{Cb}$ & $2.37 \mathrm{Bb}$ & $2.72 \mathrm{Ba}$ & $2.42 \mathrm{C}$ & $1.75 \mathrm{a}$ & $1.85 \mathrm{a}$ & $1.76 \mathrm{a}$ & $1.79 \mathrm{D}$ \\
\hline 3rd measure & $2.95 \mathrm{Ca}$ & $3.31 \mathrm{ABa}$ & $3.13 \mathrm{~B}$ & $2.13 \mathrm{Cb}$ & $2.29 \mathrm{Bb}$ & $2.58 \mathrm{Ba}$ & $2.34 \mathrm{C}$ & $3.55 \mathrm{a}$ & $2.29 \mathrm{~b}$ & $2.06 \mathrm{~b}$ & $2.63 \mathrm{~B}$ \\
\hline 4th measure & $4.19 \mathrm{Aa}$ & $3.67 \mathrm{Ab}$ & $3.93 \mathrm{~A}$ & $2.67 \mathrm{Ba}$ & $2.43 \mathrm{Ba}$ & $2.68 \mathrm{Ba}$ & $2.59 \mathrm{~B}$ & $4.04 \mathrm{a}$ & $2.51 \mathrm{~b}$ & $1.89 \mathrm{c}$ & $2.81 \mathrm{~B}$ \\
\hline 5th measure & $4.52 \mathrm{Aa}$ & $3.02 \mathrm{Bb}$ & $3.77 \mathrm{~A}$ & $3.29 \mathrm{Ab}$ & $2.92 \mathrm{Ac}$ & $4.04 \mathrm{Aa}$ & $3.42 \mathrm{~A}$ & $3.27 b$ & $3.80 \mathrm{a}$ & $3.61 \mathrm{a}$ & $3.56 \mathrm{~A}$ \\
\hline Average & $3.47 \mathrm{a}$ & $3.05 \mathrm{~b}$ & & $2.36 \mathrm{~b}$ & $2.28 \mathrm{~b}$ & $2.79 a$ & & $2.97 \mathrm{a}$ & $2.52 \mathrm{~b}$ & $2.29 \mathrm{c}$ & \\
\hline
\end{tabular}

Abbreviations: P, ploughing; DC, deep tine cultivation; SC, shallow tine cultivation; Ave., average. Different letters represent significant differences $(p<0.05)$ between tillage (lowercase), depths and measurement time (uppercase). ns, not significant at $p<0.05 .{ }^{* * *}$ Statistical significance at $p<0.001$. ${ }^{* *}$ Statistical significance at $p<0.01$. ${ }^{*}$ Statistical significance at $p<0.05$. 
According to tillage, significantly higher SPR at P than at DC were observed in 2016 at 30-40 and 40-50 cm depth. In 2017, at 20-30, 30-40 and 40-50 cm depths, SC provided significantly higher values compared to DC and P. In 2018, P had significantly higher SPR values at all depths. At $0-10 \mathrm{~cm}$ and $10-20 \mathrm{~cm}$ depths, P showed significantly greater SPR than at DC. At 20-30 cm, P had significantly higher SPR than DC and SC. However, there were significant differences detected between $P$ and SC at 30-40 and $40-50 \mathrm{~cm}$.

According to measuring time, in 2016, significant differences between P and DC occurred in 4th and 5th measurements. In 2017, significantly higher SPR were observed at SC as compared to P and DC during 1st, 2nd, 3rd and 5th measurements. During 2018, significantly higher SPR were observed at $\mathrm{P}$ as compared to DC and SC at 3rd and 4th measurements. During the 5th measurement, P resulted significantly lower SPR than the other two treatments. Single factor analyses revealed significantly higher SPR at P than at DC in 2016 and 2018. In 2017, SC showed significantly higher SPR than other treatments, while during 2018 treatments significantly differed in the following order: P > DC > SC.

\subsection{Soil Moisture Content}

Table 5 presents that all single factors as well as their interactions showed significant differences in soil moisture content (SMC) in all studied seasons.

Table 5. (a) Results of factorial ANOVA analysis for SMC. (b) Mean SMC according to the time, tillage and soil depth.

\begin{tabular}{|c|c|c|c|c|c|c|c|c|c|c|c|}
\hline \multicolumn{12}{|l|}{ (a) } \\
\hline Year & 2016 & & & 2017 & & & & 2018 & & & \\
\hline Time $(\mathrm{T})$ & $* * *$ & & & $* * *$ & & & & $* * *$ & & & \\
\hline Tillage (Till) & $* * *$ & & & $* *$ & & & & $* * *$ & & & \\
\hline Depth (D) & $* * *$ & & & $* * *$ & & & & $* * *$ & & & \\
\hline $\mathrm{T}^{*}$ Till & $* * *$ & & & $* * *$ & & & & $* * *$ & & & \\
\hline $\mathrm{T} * \mathrm{D}$ & $* * *$ & & & $* * *$ & & & & $* * *$ & & & \\
\hline Till *D & $* * *$ & & & $* *$ & & & & $*$ & & & \\
\hline $\mathrm{T} *$ Till $* \mathrm{D}$ & $* * *$ & & & $* *$ & & & & $* * *$ & & & \\
\hline \multicolumn{12}{|l|}{ (b) } \\
\hline Depth & $\mathrm{P}$ & DC & Ave. & $\mathrm{P}$ & DC & $\mathrm{SC}$ & Ave. & $\mathrm{P}$ & DC & SC & Ave. \\
\hline $0-10 \mathrm{~cm}$ & $13.4 \mathrm{Cb}$ & $17.2 \mathrm{Ca}$ & $15.3 \mathrm{C}$ & 17.5 Da & $17.6 \mathrm{Da}$ & $17.6 \mathrm{Da}$ & $17.6 \mathrm{D}$ & $13.2 \mathrm{D} \mathrm{b}$ & 15.5 Da & 15.2 Da & $14.6 \mathrm{E}$ \\
\hline $10-20 \mathrm{~cm}$ & $20.2 \mathrm{Ab}$ & $21.8 \mathrm{Aa}$ & $21.0 \mathrm{~A}$ & $25.8 \mathrm{Ca}$ & $26.3 \mathrm{Ca}$ & $26.2 \mathrm{Ca}$ & $26.1 \mathrm{C}$ & $20.8 \mathrm{Cc}$ & $24.0 \mathrm{Ca}$ & $22.9 \mathrm{Cb}$ & $22.6 \mathrm{D}$ \\
\hline $20-30 \mathrm{~cm}$ & $20.3 \mathrm{Ab}$ & $22.0 \mathrm{Aa}$ & $21.1 \mathrm{~A}$ & $27.8 \mathrm{Ba}$ & $28.1 \mathrm{Ba}$ & $27.8 \mathrm{Ba}$ & $27.9 \mathrm{~B}$ & $22.4 \mathrm{BC}$ & $25.5 \mathrm{Ba}$ & $24.5 \mathrm{Bb}$ & $24.2 \mathrm{C}$ \\
\hline $30-40 \mathrm{~cm}$ & $15.8 \mathrm{Bb}$ & $19.7 \mathrm{Ba}$ & $17.7 \mathrm{~B}$ & $29.0 \mathrm{Aa}$ & 29.2 Aa & $28.4 \mathrm{Ab}$ & $28.9 \mathrm{~A}$ & $23.9 \mathrm{Ac}$ & $26.3 \mathrm{Aa}$ & $25.6 \mathrm{Ab}$ & $25.3 \mathrm{~B}$ \\
\hline $40-50 \mathrm{~cm}$ & $12.4 \mathrm{Db}$ & $17.1 \mathrm{Ca}$ & $14.8 \mathrm{C}$ & $29.5 \mathrm{Aa}$ & $29.3 \mathrm{Aa}$ & $28.5 \mathrm{Ab}$ & $29.1 \mathrm{~A}$ & $24.5 \mathrm{Ab}$ & $26.5 \mathrm{Aa}$ & 26.1 Aa & $25.7 \mathrm{~A}$ \\
\hline \multicolumn{12}{|l|}{ Time } \\
\hline 1st measure & $18.1 \mathrm{Bb}$ & 22.2 Aa & $20.2 \mathrm{~B}$ & $24.5 \mathrm{Cb}$ & $24.7 \mathrm{Cab}$ & $25.2 \mathrm{Ca}$ & $24.8 \mathrm{C}$ & $24.3 \mathrm{Bb}$ & $24.7 \mathrm{Cab}$ & $25.0 \mathrm{~B} \mathrm{a}$ & $24.7 \mathrm{AB}$ \\
\hline 2nd measure & $20.2 \mathrm{Ab}$ & $21.7 \mathrm{Aa}$ & $21.0 \mathrm{~A}$ & $26.9 \mathrm{Ba}$ & $28.6 \mathrm{Aa}$ & $28.0 \mathrm{Aa}$ & $27.8 \mathrm{~A}$ & 19.3 Dc & $27.5 \mathrm{Aa}$ & $26.3 \mathrm{Ab}$ & $24.4 \mathrm{~B}$ \\
\hline 3rd measure & $16.0 \mathrm{Cb}$ & $17.2 \mathrm{Ca}$ & $16.6 \mathrm{C}$ & $27.9 \mathrm{Aa}$ & $26.6 \mathrm{Bb}$ & $26.3 \mathrm{Bb}$ & $26.9 \mathrm{~B}$ & 24.9 Aab & $25.4 \mathrm{Ba}$ & $24.6 \mathrm{Bb}$ & $24.9 \mathrm{~A}$ \\
\hline 4th measure & $14.8 \mathrm{Db}$ & $17.0 \mathrm{Ca}$ & $15.9 \mathrm{D}$ & $27.6 \mathrm{Ab}$ & $28.1 \mathrm{Aa}$ & 27.7 Aab & $27.8 \mathrm{~A}$ & $21.2 \mathrm{Cb}$ & $23.4 \mathrm{Da}$ & $21.7 \mathrm{Cb}$ & $22.1 \mathrm{C}$ \\
\hline 5th measure & $13.0 \mathrm{~Eb}$ & $19.6 \mathrm{~B} \mathrm{a}$ & 16.3 CD & $22.7 \mathrm{Da}$ & $22.5 \mathrm{Da}$ & $21.3 \mathrm{Db}$ & $22.2 \mathrm{D}$ & $15.0 \mathrm{E} \mathrm{b}$ & $16.8 \mathrm{Ea}$ & 16.7 Da & $16.2 \mathrm{D}$ \\
\hline Average & $16.4 \mathrm{~b}$ & $19.5 \mathrm{a}$ & & $25.9 \mathrm{a}$ & $26.1 \mathrm{a}$ & $25.7 \mathrm{~b}$ & & $21.0 \mathrm{c}$ & $23.6 \mathrm{a}$ & $22.9 \mathrm{~b}$ & \\
\hline
\end{tabular}

Abbreviations: P, ploughing; DC, deep tine cultivation; SC, shallow tine cultivation; Ave., average. Different letters represent significant differences $(p<0.05)$ between tillage (lowercase), depths and measurement time (uppercase). ns, not significant at $p<0.05$. ${ }^{* *}$ Statistical significance at $p<0.001 .{ }^{*}$ Statistical significance at $p<0.01 .{ }^{*}$ Statistical significance at $p<0.05$.

Single factor analyses showed significantly higher SMC at DC as compared to P in 2016, while in 2017 and 2018 significantly higher SMC was recorded at DC compared to SC. In 2016, SMC was significantly greater $(p<0.001)$ in DC than $P$, at all depths and time of measuring (Table 5). In 2017, at 30-40 cm and 40-50 cm depth, SC recorded significantly lower SMC than the other treatments. During individual measurements, significant differences between treatments occurred in the 1st, 3rd, 4th and 5th measurements. In 2018, significantly higher SMC was detected at DC compared to P in all examined depths. Furthermore, DC showed significantly higher SMC compared to P (2nd, 4th, 5th) or SC (2nd, 3rd, 4th) in 2018. 


\subsection{Soil Structure}

The average values of agronomic structure in tillage treatments for all years are shown in Figure 4.

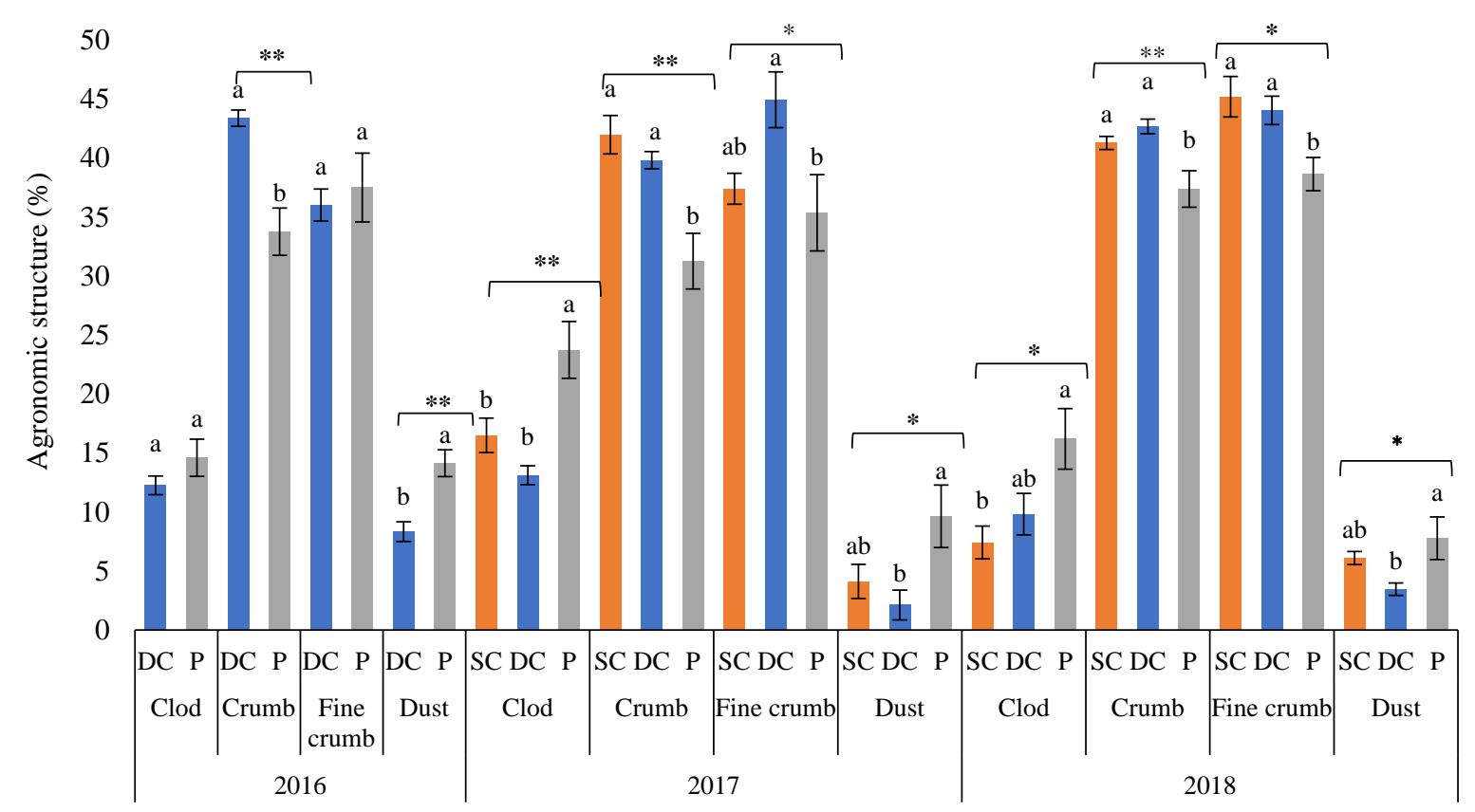

Figure 4. Average ratios of agronomic structure through three years (2016-2018). Treatments: P—ploughing; DC—deep tine cultivation; SC - shallow tine cultivation. The different lowercase letters above the columns indicate a significant difference, ${ }^{* *} p<0.01 ; * p<0.05$. Hanging bars represent standard deviation.

The dust and clod ratios were the greatest in $\mathrm{P}$ in all the three experimental years, while the crumb ratio in $\mathrm{P}$ was significantly lower than in DC and SC. The fine crumb ratio was significantly lower in P in 2017 and 2018 as compared to DC and SC.

In 2016, $\mathrm{P}$ treatment achieved higher proportions of clod $(+2.34 \%)$, fine crumb $(+1.48 \%)$ and dust $(+5.80 \%)$ compared to DC. Regarding the crumb fraction, DC showed significantly higher ratio $(+9.62 \%)$ compared to P. Furthermore, P resulted significantly higher $(5.8 \%)$ dust $(p<0.01)$ compared to DC.

In 2017, the lowest ratio of clod fraction was measured in DC $(13.12 \%)$, followed by SC $(16.50 \%)$ and the highest $(23.74 \%)$ in P, which significantly differed $(p<0.01)$ from the first two treatments. The significantly higher crumb ratio was determined in SC and DC as compared to $\mathrm{P}$, while DC showed significantly higher fine crumbs as compared to DC.

In 2018, the highest clod (16.20\%), dust (7.78\%) and lowest crumb (37.38\%) and fine crumb $(38.64 \%)$ ratios were measured in P. Significant difference $(p<0.05)$ in clod, crumb and fine crumb fractions was found between SC and $\mathrm{P}$, while in the dust fraction ratios showed significantly higher dust fraction at $\mathrm{P}$ as compared to DC $(p<0.05)$. Thus, in SC and DC significantly higher crumb $(p<0.01)$ and fine crumb ratio $(p<0.05)$ were recorded compared to $P$.

\subsection{Earthworm Abundance}

Through the three years, the effect of tillage on earthworm abundance and its temporal dynamics in 15 in situ measurements were examined (Figure 5).

In 2016, higher number of earthworms were found in DC compared to P, but the difference was not significant $(p<0.05)$. According to temporal distribution, the highest earthworm abundance was counted in DC (72 \pm 3 ind $\mathrm{m}^{-2}$ ) on 22nd July, while in P on 22nd June (48 \pm 13 ind $\mathrm{m}^{-2}$ ). During the summer months (June, July and August) earthworm abundance decreased. Compared to August, in September more earthworms 
were counted in $\mathrm{P}\left(44 \pm 8\right.$ ind $\left.\mathrm{m}^{-2}\right)$, and in DC $\left(48 \pm 23\right.$ ind $\left.\mathrm{m}^{-2}\right)$. This increase is due to an improvement in the quality of the habitat, i.e., temperature decreased, and there was $90.3 \mathrm{~mm}$ of rainfall in the meantime (Figure 2).

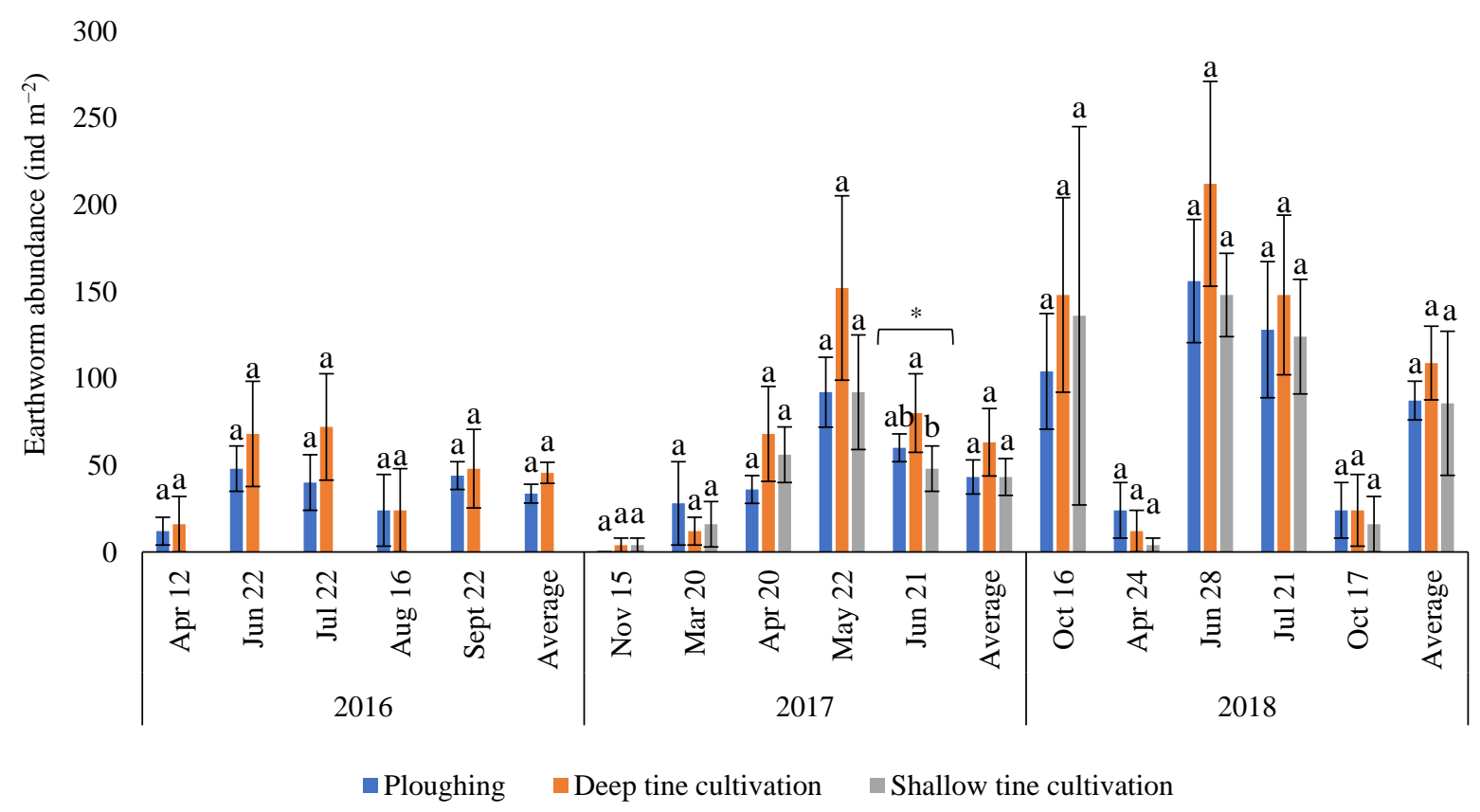

Figure 5. Earthworm abundance under different tillage treatments (2016-2018). The different lowercase letters above the columns indicate a significant difference at ${ }^{*} p<0.05$. Hanging bars represent standard deviation.

In 2017, in early spring (20th March) the highest earthworm abundance (28 \pm 24 ind $\mathrm{m}^{-2}$ ) was found in $\mathrm{P}$, followed by SC $\left(16 \pm 13\right.$ ind $\left.\mathrm{m}^{-2}\right)$, then in DC $\left(12 \pm 8\right.$ ind $\left.\mathrm{m}^{-2}\right)$. Regarding the temporal distribution, the highest earthworm abundance was recorded in May, more precisely in DC $\left(152 \pm 53\right.$ ind $\left.\mathrm{m}^{-2}\right), \mathrm{P}\left(92 \pm 20\right.$ ind $\left.\mathrm{m}^{-2}\right)$, then in SC $\left(92 \pm 33 \mathrm{ind}^{-2}\right)$. In June, with the arrival of the warmer period, the earthworm abundance decreased in all treatments, i.e., $-47.4 \%$ in DC, $-34.8 \%$ in $\mathrm{P}$ and $-47.8 \%$ in SC. This decrease resulted in a larger difference among treatments, thereby significant difference was found between DC and SC $(p<0.05)$.

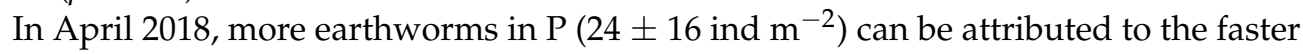
warming of the topsoil. Through the three years, the highest number of earthworms was

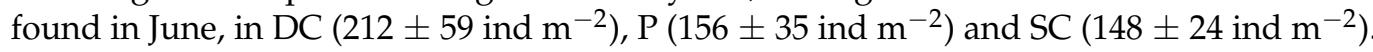
The favorable change is due to the $148.8 \mathrm{~mm}$ precipitation between the two measurements and the good condition of the soybeans.

Regarding the temporal distribution, the largest earthworm populations were observed in June 2016, May 2017 and June 2018.

\subsection{Crop Yield}

The yields are presented in $\mathrm{Mg} \mathrm{ha}^{-1}$ at dry moisture content. In 2016, the greatest maize yield was detected in DC (12.13 $\left.\mathrm{Mg} \mathrm{ha}^{-1}\right)$, followed by P (11.91 Mg ha ${ }^{-1}$ ) (Figure 6). In 2017, DC reached the highest yield $\left(7.38 \mathrm{Mg} \mathrm{ha}^{-1}\right)$, followed by SC $\left(7.14 \mathrm{Mg} \mathrm{ha}^{-1}\right)$ and P $\left(6.90 \mathrm{Mg} \mathrm{ha}^{-1}\right)$. After soybean harvest in 2018, there was no significant difference in yields between SC and P (4.20 Mg ha $\left.{ }^{-1}\right)$, while imperceptibly higher yield was obtained in DC $\left(4.22 \mathrm{Mg} \mathrm{ha}^{-1}\right)$. DC achieved the highest yields each year, while $\mathrm{P}$ reached the lowest or it was equal to SC. 


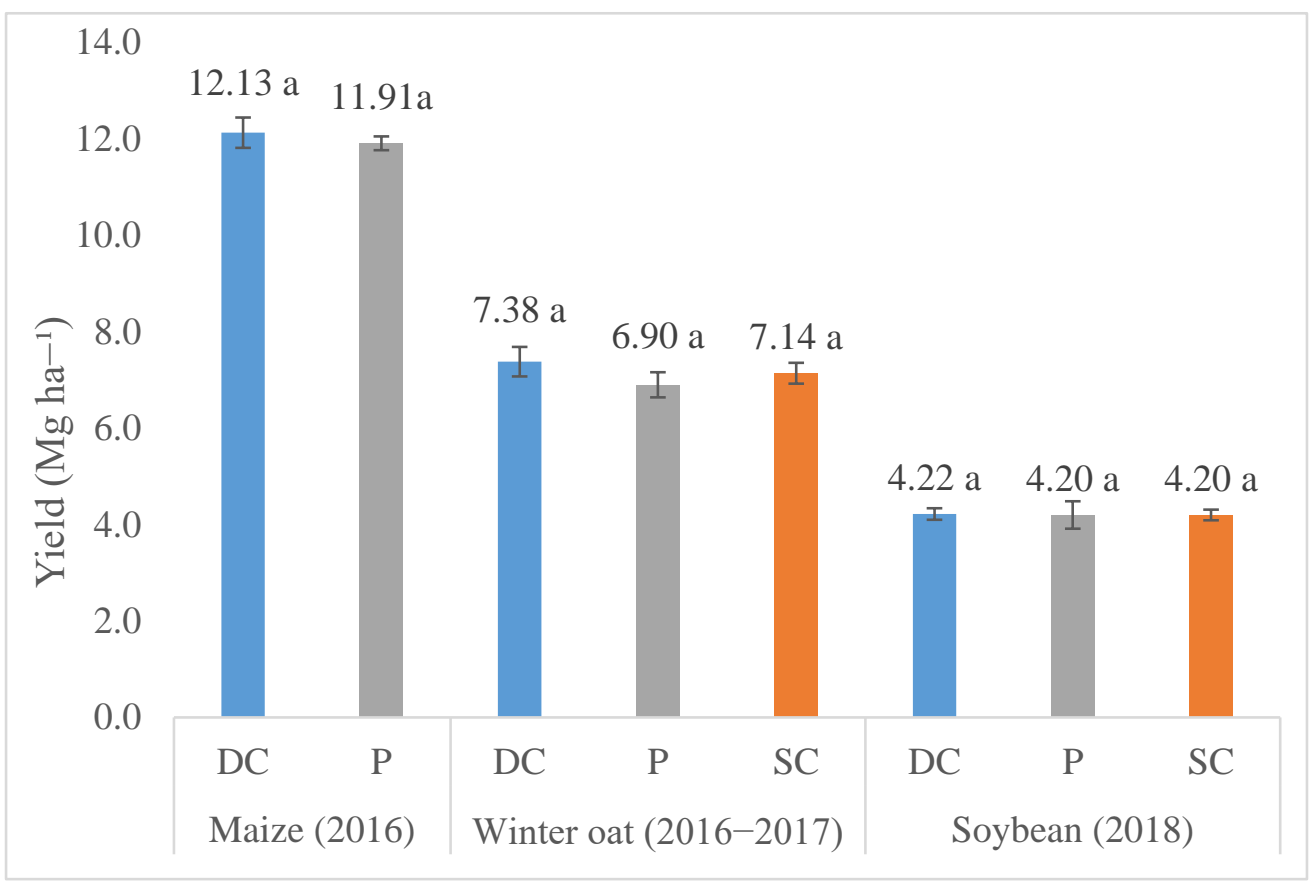

Figure 6. Grain yield on different tillage treatments in the 2016, 2017 and 2018 agricultural year. Treatments: P-ploughing; DC - deep tine cultivation; SC - shallow tine cultivation. The different lowercase letters above the columns indicate a significant difference at a $p<0.05$. Hanging bars represent standard deviation.

\section{Discussion}

\subsection{Influence of Tillage on Surface Cover}

The results of this study demonstrate how conservation tillage system (deep, DC and shallow tine cultivation, SC) can ensure proper soil cover. DC and SC showed significantly higher soil cover as compared to ploughing $(\mathrm{P})$. Such findings are in agreement with other studies $[13,21,46]$. Surface cover is extremely important for soil physical quality, especially during the summer, as it plays a major role in soil and moisture protection [13].

Differences between surface cover between DC and SC can be largely attributed to tillage depth and soil mixing. This finding also corresponds to assessments by Raper's study (2002) [47], which reported that the depth of tillage also has a significant effect on stubble residue incorporation. This was also observed by Walther (2009) [48], with a higher ratio of soil surface remaining covered by shallower tine cultivation.

\subsection{Soil Penetration Resistance}

In 2016, soil penetration resistance (SPR) was statistically higher in P than DC at 30-40 and $40-50 \mathrm{~cm}$. In 2017, significantly higher SPR was obtained in SC at 20-30,30-40 and 40-50 cm compared to P and DC. Tillage and their working depth had a variable effect on SPR. Bogunovic et al. (2018) [49] and Ren et al. (2019) [50] observed similar research findings. In addition, SPR values increased with depth to more than $4 \mathrm{MPa}$, especially from about $30 \mathrm{~cm}$ and below. Birkás et al. (2018c) [51] found the occurrence of the compact layer (plough pan) at $\sim 28 \mathrm{~cm}$ depth. The SPR in P was significantly higher than DC (0-10 and $10-20 \mathrm{~cm}$ ) in 2018 in this study.

Residue retention under DC contributed to water conservation through multiple effects on water regime which also has effects on SPR. Very low percentage of stubble residues in $\mathrm{P}[16,18]$ may negatively affect soil physical properties in several ways, such as higher soil temperature [52], higher soil evaporation [53], lower soil moisture content (SMC) [54] and greater deterioration of soil structure and soil settling [55] through the kinetic energy of raindrops. However, Afzal et al. (2008) [56] found that rapid increase of 
soil temperature in bare soil, especially in early spring, might be recognized as the crucial factor for faster seed germination.

According to the measurement time, in 2016 and 2017, the SPR values in the 1st measuring time were significantly lower than all the others. Despite the 170.5 (2016) and $148.9 \mathrm{~mm}$ (2017) precipitation between the 1st and 2nd measurements, the 2nd measurement time resulted significantly greater SPR. An additional 47.7 (2016) and $48.0 \mathrm{~mm}$ (2017) precipitation from the 3rd to the 4 th measurements contributed to a significant difference in SPR. There was significant difference between 4 th and 5 th measurements in 2017, due to the increase of temperature and low precipitation $(29.8 \mathrm{~mm})$. In 2018, the significantly lowest SPR value was in the 2nd measurement which was due to tillage operation, and it significantly differed from all the other measurements.

Considering the measurement time, the impacts of climatic conditions (heavy rainfall and its occurrence), but also water consumption are key factors. These changes in the soil are best demonstrated by experiments with artificial irrigation [57]. They highlighted that on the top of positively affecting productivity, it encourages a progressive modifying physical parameter, emphasizing greater compaction and humidity, and with lower porosity and soil weight.

\subsection{Soil Moisture Content}

In the present work conservation tillage treatments (DC and SC) resulted in relatively higher SMC in all years and measurement time as compared to $\mathrm{P}$, which supported the hypothesis in this study. The SMC values of P treatments in 2016 at 40-50 cm depth were the lowest (12.4\%). The SMC values drastically decreased in the two lower layers, which is closely associated with plough pan. In 2017, the SC as the shallowest tillage treatment gave significantly lower SMC compared to DC and P at 30-40 and 40-50 cm depth. In 2018, the SMC values in all depths were significantly greater in SC than in P. Furthermore, SMC values did not fluctuate so strongly in DC and SC as compared to P. Our study indicates that the ratio of surface cover has a positive relationship with SMC in DC and SC treatments, especially at the surface layers. Similar findings were also reported by Kalmár et al. (2013) and Dekemati et al. (2019) [13,16]. Dekemati et al. (2019) [16] found that at $10 \mathrm{~cm}$ depth, a significantly higher and the greatest SMC were measured in DC (26.06\%) as compared to P $(21.24 \%)$ which was the driest.

Current agricultural production in the Central European region is faced with unbalanced precipitation, therefore the water availability in soil is a key factor in dry farming which influences the growth and development of crops. In areas where irrigation is not possible, soil conservation practices, such as minimum disturbance and higher surface residue are highly valued as soil moisture management tools. Many papers had been published about the favorable effects of reduced disturbance and higher surface residue with the aim of better control and moisture conservation [14-16,58].

\subsection{Soil Structure}

Nowadays, due to frequent heavy rains and prolonged droughts, the protection of the soil surface with plant cover has become important. In our experiment, the highest ratio of clod was reached by $\mathrm{P}$ which is in agreement with a similar study in Hungary [59]. Weather, i.e., too high or too low temperature, strong rainfall accompanied by a strong wind and ploughing as a tillage method provide unfavorable circumstances for soil health, respectively. In addition to this, many papers had been published about positive effects of mulch residues on the soil $[11,12,18,20]$. The present results confirm previous works as DC provides the lowest ratio of dust. With similar results, Baker et al. (2005) [35] drew attention to the fact that conservation tillage achieves a 50-90\% reduction in dust fraction, especially when the number of tillage interventions is reduced. However, crumb fraction ratios between DC and SC treatments showed no difference, while both treatments showed significantly higher crumb ratio than $\mathrm{P}$. This result is not only due to the surface cover which is provided by DC and SC, but also because the other favorable soil characteristics 
of these tillage interventions, e.g., increased SMC, greater earthworm abundance, more intensive plant root growth. In contrast to $\mathrm{P}$, moderate disturbance at SC and DC, and the incorporation of plant residues into the topsoil result in favorable dynamic biological activity. A similar phenomenon was observed by Kalmár et al. (2013) and Bogunovic et al. $(2019)[13,19]$ in their relevant experiments.

\subsection{Earthworm Abundance}

This study showed that tillage did not have significant impact on earthworm abundance, except for one case (out of 15) on 21 June 2017 when DC had significantly higher abundance compared to SC. Considering the hypothesis of this work, conservation tillage significantly changed the soil conditions (greater SMC, higher ratio of crumb and lower ratio of clod and dust) which had some impacts on abundance. Which means that the hypothesis was partially justified. The earthworm abundance was greater in 11 occasions out of 15 in DC. Similar results were found Bogužas et al. (2010) [60], who compared shallow cultivated soil to $\mathrm{P}$, and found $51 \%$ more earthworms in the shallow cultivated soil. In this study, at the two early spring dates (20 March 2017 and 24 April 2018), the earthworm abundance was greater in $\mathrm{P}$, very likely due to higher soil temperatures in this treatment. In $\mathrm{P}$, the higher earthworm population is presumably attributable to the uncovered surface, which warms up faster in the spring. In line with this, Eriksen-Hamel and Whalen (2006) [61] found that abiotic factors, such as temperature and SMC, largely regulate the dynamics of earthworm populations.

\subsection{Crop Yield}

This study showed that conservation agriculture (CA) treatments (especially DC) did not result in significantly higher yields. Among the three treatments, in all the three crop years, P reached the lowest yields. Similar results were obtained by Bescansa et al. (2006) [62], who pointed out that tillage or crop residue did not have significant impact on yields. However, in dry years, ploughed treatment resulted in lower yield. In line with this, Bogunovic et al. (2020) [24] reported that crop yields increased under loosened soil compared to ploughed. Slightly higher yields in DC could be related to better retention of water through the observed soil physical properties.

\section{Conclusions}

Mulch covered treatments (deep, DC and shallow tine cultivation, SC) provide higher topsoil protection and favorable soil physical circumstances indicated by generally lower compaction, and higher water conservation as compared to uncovered ploughed soil according to this study. The soils treated with deep tine cultivator had the lowest values of soil penetration resistance (SPR), while ploughing $(\mathrm{P})$ created a compacted soil environment for plant growth. Ploughing retained less water than DC. The outcomes of this study highlighted that the use conservation tillage method (DC and SC) is more beneficial than conventional ploughing, since it increases residue cover and proportion of macro- and mezo-aggregates. The largest earthworm populations were observed in DC (11 occasions out of 15). The most favorable edaphic conditions for earthworms were provided in DC in June 2016, May 2017 and June 2018. Based on these results, it can be concluded that ploughing under the studied agro-ecological conditions should be avoided since it increases the proportion of micro-aggregates and dust, and decreases the crumb ratio. It can be assumed that changes in soil physical and biological conditions are much faster, however, the effect of these changes on the yield improvement manifests slower. Considering the erratic weather conditions, the storing of water in the soil is extremely important which can be achieved by appropriately chosen soil tillage system (in this case it was represented by DC and SC).

Author Contributions: The authors have contributed equally to the field assessment. Conceptualization, I.D., B.S., I.B., S.V., M.M.M., C.G. and M.B.; methodology, I.D., B.S. and M.B.; software, I.B., S.V. and C.G.; validation, I.D., B.S., I.B. and M.B.; formal analysis, I.D., M.M.M. and M.B.; investi- 
gation, I.D., I.B., M.M.M. and B.S.; resources, I.D. and C.G.; data curation, B.S.; writing-original draft preparation, I.D., B.S., I.B. and M.B.; writing-review and editing, B.S., I.B., C.G., S.V. and M.B.; visualization, I.B., B.S., M.B.; supervision, I.D.; project administration, I.D. and M.B.; funding acquisition, I.D. All authors have read and agreed to the published version of the manuscript.

Funding: This research was supported by the Ministry of Innovation and Technology within the framework of the Thematic Excellence Program 2020, Institutional Excellence Sub-program (TKP2020IKA-12) in the topic of water-related researches of Szent István University. This research was also supported by the Higher Education Institutional Excellence Program (NKFIH-1159-6/2019) awarded by the Ministry for Innovation and Technology within the framework of water-related research of Szent István University and by the ÚNKP-20-4-II New National Excellence Program of the Ministry for Innovation and Technology from the source of the National Research, Development and Innovation Fund. The publication is supported by the EFOP 3.6.3-VEKOP-16-2017-00008 project and by the Croatian Ministry of Science and Education and Hungarian National Research Fund trough the project number HR_HUN_2018_07 entitled “Effect of soil management on soil carbon-dioxide emission at different Croatian and Hungarian agricultural sites".

Institutional Review Board Statement: Not applicable.

Informed Consent Statement: Not applicable.

Data Availability Statement: Not applicable.

Acknowledgments: The authors with deep respect express our gratitude to Zlatko Katancic for giving agricultural land for the experiment, setting up the experiment and carrying out all the work during all the vegetation. We would like to thank the three anonymous Reviewers for their careful reading of our manuscript and their many insightful comments and suggestions which improved the paper greatly.

Conflicts of Interest: The authors declare no conflict of interest.

\section{References}

1. World Bank. 2019. Available online: https:/ / data.worldbank.org/indicator/SP.POP.TOTL?end=2019\&start=2015 (accessed on 20 May 2020).

2. Reeves, D.W. The role of soil organic matter in maintaining soil quality in continuous cropping systems. Soil Tillage Res. 1997, 43 , 131-167. [CrossRef]

3. Panagos, P.; Imeson, A.; Meusburger, K.; Borrelli, P.; Poesen, J.; Alewell, C. Soil conservation in Europe: Wish or reality? Land Degrad. Dev. 2016, 27, 1547-1551. [CrossRef]

4. Van den Akker, J.J.H.; Canarache, A. Two European concerted actions on subsoil compaction. Z. Kult. Landentwickl. 2001, 42, 15-22.

5. Pant, K.P. Effects of agriculture on climate change: A cross country study of factors affecting carbon emissions. J. Agric. Environ. 2009, 10, 84-102. [CrossRef]

6. Dekemati, I.; Simon, B.; Bogunovic, I.; Kisic, I.; Kassai, K.; Kende, Z.; Birkás, M. Long term effects of ploughing and conservation tillage methods on earthworm abundance and crumb ratio. Agronomy 2020, 10, 1552. [CrossRef]

7. Konapala, G.; Mishra, A.K.; Wada, Y.; Mann, M.E. Climate change will affect global water availability through compounding changes in seasonal precipitation and evaporation. Nat. Commun. 2020, 11, 1-10. [CrossRef]

8. Challinor, A.J.; Watson, J.; Lobell, D.B.; Howden, S.M.; Smith, D.R.; Chhetri, N. A meta-analysis of crop yield under climate change and adaptation. Nat. Clim. Chang. 2014, 4, 287-291. [CrossRef]

9. Birkás, M.; Jolánkai, M.; Kisić, I.; Stipešević, B. Soil tillage needs a radical change for sustainability. Agric. Conspec. Sci. 2008, 73, 131-136.

10. Thierfelder, C.; Mwilla, M.; Rusinamhodzi, L. Conservation agriculture in eastern and southern provinces of Zambia: Long-term effects on soil quality and maize productivity. Soil Tillage Res. 2013, 126, 246-258. [CrossRef]

11. Wang, S.; Guo, L.; Zhou, P.C.; Wang, X.; Shen, Y.; Han, H.; Ning, T.; Han, K. Effect of subsoiling depth on soil physical properties and summer maize (Zea mays L.) yield. Plant Soil Environ. 2019, 65, 131-137. [CrossRef]

12. Jourgholami, M.; Fathi, K.; Labelle, E.R. Effects of litter and straw mulch amendments on compacted soil properties and Caucasian alder (Alnus subcordata) growth. New For. 2019, 51, 349-365. [CrossRef]

13. Kalmár, T.; Bottlik, L.; Kisić, I.; Gyuricza, C.; Birkás, M. Soil protecting effect of the surface cover in extreme summer periods. Plant Soil Environ. 2013, 59, 404-409. [CrossRef]

14. Powlson, D.S.; Stirling, C.M.; Jat, M.L.; Gerard, B.G.; Palm, C.A.; Sanchez, P.A.; Cassman, K.G. Limited potential of no-till agriculture for climate change mitigation. Nat. Clim. Chang. 2014, 4, 678-683. [CrossRef]

15. Mkoga, Z.J.; Tumbo, S.D.; Kihupi, N.; Semoka, J. Extrapolating effects of conservation tillage on yield, soil moisture and dry spell mitigation using simulation modelling. Phys. Chem. Earth Part A/B/C 2010, 35, 686-698. [CrossRef] 
16. Dekemati, I.; Simon, B.; Vinogradov, S.; Birkás, M. The effects of various tillage treatments on soil physical properties, earthworm abundance and crop yield in Hungary. Soil Tillage Res. 2019, 194, 104334. [CrossRef]

17. Giannitsopoulos, M.L.; Burgess, P.J.; Rickson, R.J. Effects of conservation tillage drills on soil quality indicators in a wheat-oilseed rape rotation: Organic carbon, earthworms and water-stable aggregates. Soil Use Manag. 2019, 36, 139-152. [CrossRef]

18. Dekemati, I.; Bogunovic, I.; Kisic, I.; Radics, Z.; Szemők, A.; Birkás, M. The effects of tillage-induced soil disturbance on soil quality condition. Pol. J. Environ. Stud. 2019, 28, 3665-3673. [CrossRef]

19. Bogunovic, I.; Kovács, G.P.; Dekemati, I.; Kisic, I.; Balla, I.; Birkás, M. Long-term effect of soil conservation tillage on soil water content, penetration resistance, crumb ratio and crusted area. Plant Soil Environ. 2019, 65, 442-448. [CrossRef]

20. Birkás, M.; Jolánkai, M.; Gyuricza, C.; Percze, A. Tillage effects on compaction, earthworms and other soil quality indicators in Hungary. Soil Tillage Res. 2004, 78, 185-196. [CrossRef]

21. Birkás, M.; Dekemati, I.; Kisić, I.; Pósa, B. Results of the soil quality preservation in the extreme seasons. In Proceedings of the 10th International Scientific/Professional Conference, Agriculture in Nature and Environment Protection, Vukovar, Croatia, 5-7 June 2017; pp. 10-19.

22. Morris, N.L.; Miller, P.C.H.; Orson, J.H.; Froud-Williams, R.J. The adoption of non-inversion tillage systems in the United Kingdom and the agronomic impact on soil, crops and the environment-A review. Soil Tillage Res. 2010, 108, 1-15. [CrossRef]

23. Gao, Y.; Dang, X.; Yu, Y.; Li, Y.; Liu, Y.; Wang, J. Effects of tillage methods on soil carbon and wind erosion. Land Degrad. Dev. 2016, 27, 583-591. [CrossRef]

24. Bogunovic, I.; Pereira, P.; Galic, M.; Bilandzija, D.; Kisic, I. Tillage system and farmyard manure impact on soil physical properties, CO2 emissions, and crop yield in an organic farm located in a Mediterranean environment (Croatia). Environ. Earth Sci. 2020, 79, 1-11. [CrossRef]

25. Yasmin, S.; D'Souza, S. Effects of pesticides on the growth and reproduction of earthworm: A review. Appl. Environ. Soil Sci. 2010, 2010, 1-9. [CrossRef]

26. Van Capelle, C.; Schrade, S.; Brunotte, J. Tillage-induced changes in the functional diversity of soil biota-A review with a focus on German data. Eur. J. Soil Biol. 2012, 50, 165-181. [CrossRef]

27. Blouin, M.; Hodson, M.E.; Delgado, E.A.; Baker, G.; Brussaard, L.; Butt, K.R.; Dai, J.; Dendooven, L.; Pérés, G.; Tondoh, J.E.; et al. A review of earthworm impact on soil function and ecosystem services. Eur. J. Soil Sci. 2013, 64, 161-182. [CrossRef]

28. Singh, J.; Cameron, E.; Reitz, T.; Schädler, M.; Eisenhauer, N. Grassland management effects on earthworm communities under ambient and future climatic conditions. Eur. J. Soil Sci. 2021, 72, 343-355. [CrossRef]

29. Lee, K.E. Earthworms: Their Ecology and Relationship with Soils and Land Use; Academic Press: Sydney, Australia, 1985; pp. 351-388.

30. Pelosi, C.; Barot, S.; Capowiez, Y.; Hedde, M.; Vandenbulcke, F. Pesticides and earthworms: A review. Agron. Sustain. Dev. 2014, 34, 199-228. [CrossRef]

31. Johnston, A.S.A.; Sibly, R.M.; Hodson, M.E.; Alvarez, T.; Thorbek, P. Effects of agricultural management practices on earthworm populations and crop yield: Validation and application of a mechanistic modelling approach. J. Appl. Ecol. 2015, 52, 1334-1342. [CrossRef]

32. Johnston, A.S.A.; Sibly, R.M.; Thorbek, P. Forecasting tillage and soil warming effects on earthworm populations. J. Appl. Ecol. 2018, 55, 1498-1509. [CrossRef]

33. Sankar, A.S.; Patnaik, A. Impact of soil physico-chemical properties on distribution of earthworm populations across different land use patterns in southern India. J. Basic Appl. Zool. 2018, 79, 50. [CrossRef]

34. Singh, J.; Schädler, M.; Demetrio, W.; Brown, G.G.; Eisenhauer, N. Climate change effects on earthworms-A review. Soil Org. 2019, 91, 114-138. [CrossRef] [PubMed]

35. Baker, J.B.; Southard, R.J.; Mitchell, J.P. Agricultural dust production in standard and conservation tillage systems in the San Joaquin Valley. J. Environ. Qual. 2005, 34, 1260-1269. [CrossRef] [PubMed]

36. Munkholm, L.J.; Heck, R.J.; Deen, B. Long-term rotation and tillage effects on soil structure and crop yield. Soil Tillage Res. 2013, 127, 85-91. [CrossRef]

37. Busari, M.A.; Kukal, S.S.; Kaur, A.; Bhatt, R.; Dulazi, A.A. Conservation tillage impacts on soil, crop and the environment. Int. Soil Water Conserv. Res. 2015, 3, 119-129. [CrossRef]

38. Jug, D.; Birkás, M.; Šeremešić, S.; Stipešević, B.; Jug, I.; Žugec, I.; Đalović, I. Status and perspective of soil tillage in South-East Europe. In Proceedings of the CROSTRO-Croatian Soil Tillage Research Organization: 1st International Scientific Conference, Osijek, Croatia, 9-11 September 2010; p. 50.

39. Känkänen, H.; Alakukku, L.; Salo, Y.; Pitkänen, T. Growth and yield of spring cereals during transition to zero tillage on clay soils. Eur. J. Agron. 2011, 34, 35-45. [CrossRef]

40. Liu, Z.; Gao, T.; Tian, S.; Hu, H.; Li, G.; Ning, T. Soil organic carbon increment sources and crop yields under long-term conservation tillage practices in wheat-maize systems. Land Degrad. Dev. 2020, 31, 1138-1150. [CrossRef]

41. Jug, D.; Krnjaić, S.; Stipešević, B. Prinos ozime pšenice (Triticum aestivum L.) na različitim varijantama obrade tla. Poljoprivreda 2006, 12, 47-52.

42. Bogunovic, I.; Trevisani, S.; Seput, M.; Juzbasic, D.; Đurdevic, B. Short-range and regional spatial variability of soil chemical properties in an agro-ecosystem in eastern Croatia. Catena 2017, 154, 50-62. [CrossRef] 
43. International Union of Soil Sciences Working Group WRB. World Reference Base for Soil Resources 2.14 (Update 2015), International Soil Classification System for Naming Soils and Creating Legends for Soil Maps; World Soil Resources Reports No. 106; FAO: Rome, Italy, 2015; Available online: http:/ / www.fao.org/3/a-i3794e.pdf (accessed on 15 May 2018).

44. Stefanovits, P. Talajtan; Mezőgazda Kiadó: Budapest, Hungary, 1992.

45. International Organization for Standardization. Soil Quality-Determination of Particle Size Distribution in Mineral Soil MaterialMethod by Sieving and Sedimentation. In ISO 11277; International Organization for Standardization: Geneve, Switzerland, 1998.

46. Jug, D.; Brozović, B.; Đurđević, B.; Jug, I.; Lipiec, J.; Birkás, M.; Vukadinović, V. Effect of conservation tillage on crop productivity and nitrogen use efficiency. Soil Tillage Res. 2019, 194, 104327. [CrossRef]

47. Raper, R.L. The influence of implement type, tillage depth, and tillage timing on residue burial. Trans. ASAE 2002, 45, 1281-1286. [CrossRef]

48. Walther, S. Variable Bodenbearbeitungsintensität: Ein Beitrag zum Nachhaltigen Bodenschutz; Kovač: Hamburg, Germany, 2009 ; p. 166.

49. Bogunovic, I.; Pereira, P.; Kisic, I.; Sajko, K.; Sraka, M. Tillage management impacts on soil compaction, erosion and crop yield in Stagnosols (Croatia). Catena 2018, 160, 376-384. [CrossRef]

50. Ren, L.; Nest, T.V.; Ruysschaert, G.; D'hose, T.; Cornelis, W.M. Short-term effects of cover crops and tillage methods on soil physical properties and maize growth in a sandy loam soil. Soil Tillage Res. 2019, 192, 76-86. [CrossRef]

51. Birkás, M.; Jug, D.; Kende, Z.; Kisić, I.; Szemők, A. Soil tillage response to the climate threats-Revaluation of the classic theories. Agric. Conspec. Sci. 2018, 93, 1-9.

52. Dahiya, R.; Ingwersen, J.; Streck, T. The effect of mulching and tillage on the water and temperature regimes of a loess soil: Experimental findings and modeling. Soil Tillage Res. 2007, 96, 52-63. [CrossRef]

53. Kader, M.A.; Senge, M.; Mojid, M.A.; Nakamura, K. Mulching type-induced soil moisture and temperature regimes and water use efficiency of soybean under rain-fed condition in central Japan. Int. Soil Water Conserv. Res. 2017, 5, 302-308. [CrossRef]

54. Tao, Z.; Li, C.; Li, J.; Ding, Z.; Xu, J.; Sun, X.; Zhou, P.; Zhao, M. Tillage and straw mulching impacts on grain yield and water use efficiency of spring maize in Northern Huang-Huau-Hai Valley. Crop J. 2015, 3, 445-450. [CrossRef]

55. Nanko, K.; Giambelluca, T.W.; Sutherland, R.A.; Mudd, R.G.; Nullet, M.A.; Ziegler, A.D. Erosion potential under Miconia calvescens Stands on the Island of Hawai'i. Land Degard. Dev. 2012, 26. [CrossRef]

56. Afzal, I.; Basra, S.M.A.; Shahid, M.; Farooq, M.; Saleem, M. Priming enhances germination of spring maize (Zea Mays L.) under cool conditions. Seed Sci. Technol. 2008, 36, 497-503. [CrossRef]

57. Rodríguez Sousa, A.A.; Barandica, J.M.; Rescia, A. Ecological and economic sustainability in olive groves with different irrigation management and levels of erosion: A case study. Sustainability 2019, 11, 4681. [CrossRef]

58. Bottinelli, N.; Angers, A.D.; Hallaire, V.; Michot, D.; Le Guillou, D.; Cluzeau, D.; Heddadj, D.; Menasseri-Aubry, S. Tilllage and fertilization practices affect soil aggregate stability in a Humic Cambisol of Northwest France. Soil Tillage Res. 2017, 170, 14-17. [CrossRef]

59. Bencsik, K. Talajmúvelési módok és a talaj agronómiai szerkezetének összefüggései. Agrokémia Talajt. 2007, 56, 21-28.

60. Bogužas, V.; Kairyté, A.; Jodaugiené, D. Soil physical properties and earthworms as affected by soil tillage systems, straw and green manure management. Zemdirb.-Agric. 2010, 97, 3-14.

61. Eriksen-Hamel, N.S.; Speratti, A.B.; Whalen, J.K.; Légére, A.; Madramootoo, C.A. Earthworm populations and growth rates related to long-term crop residue and tillage management. Soil Tillage Res. 2009, 104, 311-316. [CrossRef]

62. Bescansa, P.; Imaz, M.J.; Virto, I.; Enrique, A.; Hoogmoed, W.B. Soil water retention as affected by tillage and residue management in semiarid Spain. Soil Tillage Res. 2006, 87, 19-27. [CrossRef] 